\title{
On the ideal concept of police for Mexico City
}

\author{
D. Santos-Reyes ${ }^{1} \&$ J. Santos-Reyes ${ }^{2}$ \\ ${ }^{1}$ Manufacturing and Systems Research Group, \\ Universidad Tecnológica de la Mixteca, México \\ ${ }^{2}$ Safety, Risk \& Reliability Research Group, SEPI-ESIME, \\ National Polytechnic Institute, Mexico
}

\begin{abstract}
Mexicans are fearful and concerned about the increasing number of crimes of all kinds that have permeated the fabric of their cities and communities. Law enforcement institutions are unfit for purpose, characterised by corrupt practices, and low levels of education and training. Often, the law enforcement officers have violated the civil rights of ordinary citizens, and even murdered several members of civil organisations. Moreover, many police officers are part of organised crime. What would be the ideal concept of police for Mexico City? There is a need to reformulate the concept of police in order to approach crime more effectively. This paper outlines a particular approach that has being employed in order to develop an ideal concept of police for Mexican law enforcement institutions. It is hoped that this concept might help law enforcement institutions to change the current concept of police so that they can approach crime and at the same time protect civilians more effectively.
\end{abstract}

Keywords: police concept, creative design, crime, grounded theory.

\section{Introduction}

Mexicans are fearful and concerned not only about the increasing number of crimes that have permeated the fabric of their cities and communities [1,2], but also about the number of crimes committed by the law enforcement authority itself. It seems that law enforcement institutions are unfit for purpose, characterised by corrupt practices, and low levels of education and training. Often, the law enforcement officers have violated the civil rights of ordinary citizens, such as unlawful deprivation of life, disappearances, arbitrary arrest, 
arbitrary interference with privacy, and disrespect for civil liberties $[3,4]$. Moreover, many police officers are part of organised crime [5].

Not only has organised crime increased, but also the violation of political rights has increased. For example, the murder of 45 indigenous people in Acteal, Chiapas (1997) and 17 in Aguas Blancas, Guerrero (1995); more recently, the uncontrolled use of law enforcement officers to control demonstrations have violated the civil rights of ordinary citizens, and several members of civil organisations in Atenco and Oaxaca (2006) [2] have even been murdered. Both academia and the public sector have paid significant attention to the development of approaches to crime prevention and control issues. However, little attention has been given to the redesign of the police and policing. There is a need to reformulate the concept of police and policing in order to ensure public safety. This research project addresses the following question: What would be the ideal concept of police for Mexico City? It uses the method of Grounded Theory in order to analyse the data gathered in "the police we want" by NGOs for Mexico City [6].Then it uses the results in order to develop an understanding of an ideal police concept for Mexico City. In the remaining sections of the paper, the literature review, the grounded theory method, preliminary results, and conclusions and further research are presented.

\section{Crime science and creative design}

\subsection{Crime science}

Approaches to crime have evolved from trial and error to methods and techniques of science. Law enforcement and related institutions have been working hard to dismantle long-standing barriers that separate them from scientific methods and the traditional way of approaching crime. This way of approaching crime is known as crime science. Crime science embraces, among other things, disciplines, such as engineering design, biochemistry, material science, criminology, psychology, sociology, communications, artificial intelligence, zoology, and ecology [7]. Significant developments on the theory of policing have taken place over the last few years. There is a growing importance of a cluster of concepts, such as intelligence, knowledge, information technology, data mining, and networks [8]. Special attention has been given to the development and implementation of intelligence models in order to understand the criminal environment, assist decision-makers and make an impact on the criminal environment [9]. The effective communication of violence risk information to forensic decision makers [10] is becoming increasingly important. With the aim of improving police performance, there has been an increasing interest in higher education in crime and justice studies in order to professionalise the police [11].

Community policing consists of community-oriented and problem-oriented policing [12]. The community-oriented policing focuses more on fear of crime and better relations with the community than on crime itself. Problem-oriented policing, on the other hand, focuses on identifying and solving problems that 
cause disorder and crime at micro level. Although law enforcement institutions have achieved significant progress, organised crime has adapted successfully to the process of globalisation and law enforcement institutions still experience difficulties dealing with it [13]. These institutions are making significant efforts to incorporate new crimes, such as bias crime, cyber-crime, and stalking, into their responsibilities [14]. McLaughlin [15] examines how the police constable, known as the 'bobby on the beat', the foundation stone of English policing, was created. This concept of a police officer has acquired a representative status in many countries that supports the culture and beliefs of the people. Famega et al. [16] contend that police work is both reactive and proactive. It is reactive because police officers know in advanced their workload for the uncommitted portion of their patrol time. The proactive aspect of patrol work is still ambiguous because the conduct and effect of preventive patrol are not clear, and many of the self-initiated activities are not strictly crime-or non-crime-related.

\subsection{Creative design}

Design is a conscious process by which an idea is transformed into tangible or intangible products [17]. Engineers use this process, including tools and methods for solving problems, meeting needs, improving situations, or creating something new. Improving existing products is normally called incremental innovation, and at the other end of the continuum creating totally new products is known as radical innovation. Innovation is about adding or creating value. For this reason design is recognised as a creative process. Historically the decision-making in the design process has been trial and error. This approach has been enhanced by methods, such as brainstorming [18], morphological analysis [19], and synectics [20], which aim at breaking what is believed to be mental blocks when developing new solutions. More advanced approaches to idea generation emphasise the systematic decomposition and analysis of the design problem [21]. These methods are based on knowledge-based principles and the application of physical and chemical phenomena.

According to Simon [22], creativity is the ability to produce something that is both novel (original or unexpected) and appropriate (useful). Creative people use what already exists and change it into something that did not exist before. Because creativity has to do with the production of new ideas, it involves cognition that seems only to occur within a framework of associated motivational, attitudinal, and personality traits. The combination of components in a new way generally involves the perception of an analogy. For example, Alexander Graham Bell was puzzled that a small membrane in the human ear, the ear drum, could vibrate powerfully enough to move the solid bones that made up the ear's mechanism. The analogy is that a similar membrane could be used to control the flow of an electric current in response to the air waves made by sound. This insight was the breakthrough that Bell used to invent the telephone. However, the analogy might come from the engineering point of view. Altshuller [21] states that an ideal machine is a machine that performs a desired function without actually existing. This machine is weightless, has no cost, does not occupy any space or produce any harm. The underlying point is that there is no 
need for the system or machine, rather there is the need for the useful functions provided by the systems.

\subsection{Approaching crime in Mexico}

Over the last few years, there has been a great effort from the Mexican government, NGOS, and the ordinary Mexicans to approach crime. In general it is believed that the lack of an effective control system leads to the poor performance of the Mexican justice system [23]. The preventive police have no clear functions since they perform administrative functions rather than ensuring order [24]. Mexico City policing is characterised by a lack of crime investigation, making illegal profits, and abuse [25]. What would be the ideal concept of police for Mexico City? In order to change this, there is the need for resources for training and education, and reduce corruption practices [26,27]. Piccato [28] analyses the perception of crime during the last century in Mexico City. Other studies develop measures of social constructs, such as interpersonal trust, networking, membership, fear, well-being, and institutional trust [29].

\section{Policing in Mexico}

\subsection{The context}

Policing in Mexico essentially is achieved by the ministries of public security, including the attorney general's office (PGR), the states attorney general's offices (PGJEs), and the federal district attorney general's office (PGJDF). These institutions are perceived by the vast majority of Mexicans as of poor performance, with corruption practices and a high level of impunity. The PGR, PGJEs and PGJDF are in charge of investigating crimes and prosecuting suspects, and ensuring that the legal rights and guarantees of citizens are fully respected. These institutions also have the responsibility for investigating complaints of human rights violations by police officers. However, the PGR, PGJDF and the PGJEs are often subordinated to the Federal and State executives. Thus, they are acting in the direct interest of the current president or state governor, rather than as an independent prosecutor upholding the rule of law. Moreover, they have repeatedly failed to prevent and investigate crimes of all kinds and have remained subordinated to the interests of the very few who have sought to prevent access to the truth and justice.

Over the last decade Mexicans have realised demonstrations throughout the country to express their concern about the increasing rate of crime, such as violence against women, kidnappings, murders, violation of the rights of minority groups, the murder of journalists, disappearances, drug trafficking and associated violence, and the excessive use of force in the practice of policing. Very little attention has been given to address policing practices, which have facilitated the growth of organised crime, and different manifestations of crime that have deeply permeated the fabric of the entire country. 


\subsection{Data analysis}

The information required for this study is data on "the police we want for Mexico City" as organised and gathered by NGOs [6]. The analysis of this data follows the Grounded Theory (GT) as proposed by Glaser and Strauss [30]. GT investigates the actualities in the real world and analyses the data with no preconceived hypothesis. Data collection is usually, but not exclusively, by interviews. Data analysis involves searching out the concepts behind the actualities by looking for codes, then concepts and finally categories. GT coding is a form of content analysis to find and conceptualise the underlying issues amongst the noise of the data by highlighting an issue of interest to the researcher from the words and phrases of the interviewee. This is noted and described in a short phrase. This issue may be mentioned again in the same or similar words and is again noted. This process is called coding and the short descriptor phrase is a code. The process of coding should be performed with an open mind without preconceived ideas. Codes emerge from identifying points, key to addressing research questions. The codes are then analysed and those that relate to a common theme are grouped together. This higher order affinity is called a concept. Concepts are then grouped and regrouped to find yet higher order commonalities called categories. It is these concepts and categories that lead to the emergence of a theory. If the data is analysed without a preconceived theory or hypothesis, that theory is truly grounded in the data because it came from nowhere else.

\section{The emergence of an ideal police concept}

In order to develop alternative concepts, conceptual design requirements or needs have to be defined. The emergence of concepts is presented first; then the emergence of categories, or requirements as called here, are discussed.

\subsection{The emergence of concepts}

The code "incorruptible" emerged from $\mathrm{P}_{1}$. The codes from all other key points were compared with this to see if similar codes occurred often. The following codes were considered to have affinity: "honest" from $\mathrm{P}_{2}$; "should not bribe" from $\mathrm{P}_{3}$; "corruption" from $\mathrm{P}_{4}$; "profits from corruption" from $\mathrm{P}_{5}$; "extortionate police" from $\mathrm{P}_{7}$. The common characteristic is "Incorruptible and honest" and this was one of the concepts to emerge from the data. This was noted in Table 1.

From $\mathrm{P}_{8}$ to $\mathrm{P}_{13}$ emerged "Good manners", "Professional culture", "Education", "training and courses" and "values and citizenship". Combining these lead to the concepts of "Education on values and policing culture", "Continuous training on values by professionals". Other combinations were identified and recorded. Confidence in the process of coding grew and uncertain subsiding with experience of the method.

The process of comparing the codes with each other, to find higher order affinity, produced the concepts from the codes. Some concepts from the whole process are summarised in Table 1. 
Table 1: $\quad$ Some of the concepts that emerged from the coding process.

\begin{tabular}{|c|c|c|c|}
\hline I.D. & Key point & Code & Concept \\
\hline $\mathrm{P}_{1}$ & $\begin{array}{l}\text { Incorruptible police in the entire } \\
\text { organisation }\end{array}$ & \multirow{7}{*}{$\begin{array}{l}\text { Incorruptible } \\
\text { Honest } \\
\text { Should not bribe } \\
\text { Corruption } \\
\text { Profits from corruption } \\
\text { Protection } \\
\text { Extortionate police }\end{array}$} & \multirow{7}{*}{$\begin{array}{l}\text { Police should be } \\
\text { incorruptible and } \\
\text { honest. } \\
\begin{array}{l}\text { Corruption is more } \\
\text { profitable. }\end{array}\end{array}$} \\
\hline $\mathrm{P}_{2}$ & $\begin{array}{l}\text { Police should be honest in the entire } \\
\text { organisation }\end{array}$ & & \\
\hline $\mathrm{P}_{3}$ & $\begin{array}{l}\text { Police should not bribe citizens or } \\
\text { offenders }\end{array}$ & & \\
\hline $\mathrm{P}_{4}$ & $\begin{array}{l}\text { There are corruption acts in all levels of } \\
\text { the organisation }\end{array}$ & & \\
\hline $\mathrm{P}_{5}$ & $\begin{array}{l}\text { Police get more profits from corruption } \\
\text { activities }\end{array}$ & & \\
\hline $\mathrm{P}_{6}$ & Police protect criminals & & \\
\hline $\mathrm{P}_{7}$ & Bosses extortionate police officers & & \\
\hline $\mathrm{P}_{8}$ & Police with good manners & \multirow{6}{*}{$\begin{array}{l}\text { Good manners } \\
\text { Professional culture } \\
\text { Education } \\
\text { Values and citizenship } \\
\text { Training and courses }\end{array}$} & \multirow{6}{*}{$\begin{array}{l}\text { Education on values } \\
\text { and policing culture. } \\
\text { Professional police. } \\
\text { Continuous training } \\
\text { on values by } \\
\text { professionals. }\end{array}$} \\
\hline $\mathrm{P}_{9}$ & Police with knowledge of basic functions & & \\
\hline $\mathrm{P}_{10}$ & Police with academic degree & & \\
\hline $\mathrm{P}_{11}$ & Police with values and citizenship & & \\
\hline $\mathrm{P}_{12}$ & $\begin{array}{l}\text { Training and courses on values, reliability, } \\
\text { emotional, working consciousness and } \\
\text { human relations }\end{array}$ & & \\
\hline$P_{13}$ & $\begin{array}{l}\text { High quality and efficient training by } \\
\text { professionals }\end{array}$ & & \\
\hline
\end{tabular}

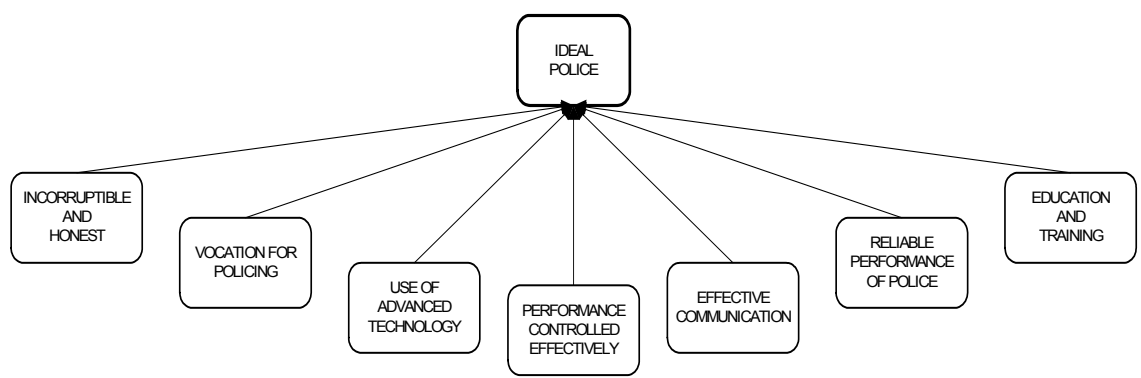

Figure 1: $\quad$ Emergent categories and theory from grounded theory analysis.

\subsection{The emergence of categories}

By comparing each concept in turn with all other concepts, further commonalities are found which form the even broader categories. By applying the constant comparison technique to each concept in turn, an affinity theme was found amongst the following concepts: "Police should be incorruptible and honest" and "corruption is more profitable". These share the theme of "Police should be incorruptible and honest". By comparing the other concepts and grouping common themes new categories emerged, as shown in Figure 1.

The emergent grounded theory of an ideal concept of police can be summarized as a set of attributes that collectively form a mechanism to assist the effective operation of a police officer. The usefulness of an ideal concept will be impaired if the benefits from it are not recognized and supported among 
decision-makers. This system of attributes will assist in identifying conflicting aspects by analysing their interactions and relationships between them so that a more radical concept of police can be created.

\section{Conclusions and further research}

This paper presented the preliminary results on the ideal concept of police for Mexico City. It uses the Grounded Theory method to analyse data, gathered by some Mexican NGOs, and draw meaningful characteristics of an ideal police. Although the results of this study are not strictly conclusive, it has several implications for policy-makers and decision-takers. By using the categories as requirements may help to develop a robust police concept, which would satisfy Mexicans' needs for effective police officers. Future research includes using the categories and creative thinking to further develop the concept of an ideal police for Mexico City.

\section{References}

[1] Shelley, L., Corruption and Organised Crime in Mexico in the Post-PRI Transition, Journal of Contemporary Criminal Justice, Vol. 17 No.3, August 2001, pp. 213-231.

[2] Santos-Reyes, D. and Santos-Reyes, J., Patterns and rates of crime evolution in Mexico, WIT Transactions on the Built Environment, 2007, pp. 119-127.

[3] Mexico: "Disappearances": an ongoing crime. Amnesty International (AI), Library Web site. http://web.amnesty.org/library/Index/ENGAMR 410202002.

[4] 2008 Human Rights Report: Mexico, Bureau of Democracy, Human Rights, and Labour, Library Web site. http://www.state.gov/g/drl /rls/hrrpt/2008/wha/119166.htm.

[5] State of Siege: Drug-related violence and corruption in Mexico, Washington Office on Latin America (WOLA), June 2006. http://www.wola.org/publications/publications.htm.

[6] La policía que queremos: consulta ciudadana, http://www. apoliciaquequeremos.org.mx.

[7] Smith, M.J. \& Tilley, N., (eds.), Crime Science: New approaches to preventing and detecting crime. Willan Publishing, 2005.

[8] Brodeur, J.P: \& Dupont, B., Knowledge workers or "knowledge" workers?, Policing and society, Vol. 16, Number 1, pp. 7-26, March 2006.

[9] Ratcliffe, J., The effectiveness of police intelligence management: a New Zealand Case Study, Police Practice and Research, Vol. 6, No. 5, December, pp. 435-451.

[10] Hilton, N.Z., Harris, G.T., Rawson, K., and Beach, C.A., Communicating violence risk information to forensic decision makers, Criminal Justice and Behaviour, Vol. 32, No. 1, February, pp. 097-116. 
[11] Finckenauer, J.O., The quest for quality in criminal justice education, Justice Quarterly, Vol. 22, Number 4, December, pp. 413-426.

[12] Bichler, G., and Gaines, L., An examination of police officers' insights into problem identification and problem solving, Crime and Delinquency, Vol. 51, Num. 1, January, pp. 53-74.

[13] Griffiths, H., Smoking guns: European cigarette smuggling in the 1990's, Global Crime, Vol. 6, No. 2, May, pp. 185-200.

[14] Barnett-Ryan, C., and Nolan, J.J., Impact of state UCR policy and procedures on bias crime reporting, Criminal Justice Studies, Vol. 18, No. 4, December, pp. 305-319.

[15] McLaughlin, E., From reel to ideal: the blue lamp and the popular cultural construction of the English 'bobby', Crime Media Culture, Vol. 1(1), pp. 11-30.

[16] Famega, C.N., Frank, J., and Mazerolle, L., Managing police patrol time: the role of supervisor directives, Justice Quarterly, Vol. 22, Num. 4, pp. 540-559.

[17] Von Stamm, B., About: Innovation, Design Council, http://www. designcouncil.org.uk.

[18] Osborn, A., Applied imagination, Scribner, N.Y., 1979.

[19] Zwicky, P., Discovery, invention, research through morphological analysis, McMillan, N.Y., 1969.

[20] Gordon, W.J., Synectics, the development of creative capacity, Harper, N.Y., 1961.

[21] Altshuller, G., Creativity as an exact science, Gordon and Breach Publisher, 1984.

[22] Simon, H.A., Discovery, invention and development: human creative thinking, Proceedings of the National Academy of Science, Vol. 80, pp. 4569-4571.

[23] La investigación de los delitos y la subversión de los principios del subsistema penal en México, (May 15, 2003). Centre for U.S.-Mexican Studies. Project on Reforming the Administration of Justice in Mexico. http://www.repositories.cdlib.org/usmex/prajm/zepeda.

[24] Policía preventiva en la región central de México y el modelo gatadino de seguridad interior. (May 15, 2003). Centre for U.S.-Mexican Studies. Project on Reforming the Administration of Justice in Mexico. http://www.repositories.cdlib.org/usmex/prajm/yanez.

[25] Abuso policial en la ciudad de México. (May 15, 2003). Centre for U.S.Mexican Studies. Project on Reforming the Administration of Justice in Mexico. http://www.repositories.cdlib.org/usmex/prajm/silva.

[26] Police forces in Mexico: a profile. (May 15, 2003). Centre for U.S.Mexican Studies. Project on Reforming the Administration of Justice in Mexico. http://www.repositories.cdlib.org/usmex/prajm/reames.

[27] Educación y entrenamiento policial para la democracia. (May 15, 2003). Centre for U.S.-Mexican Studies. Project on Reforming the Administration of Justice in Mexico. http://www.repositories.cdlib.org/usmex/ prajm/lopez_portillo. 
[28] A historical perspective on crime in twentieth-century Mexico City. (May 15, 2003). Centre for U.S.-Mexican Studies. Project on Reforming the Administration of Justice in Mexico. http://www.repositories.cdlib.org/ usmex/prajm/piccato.

[29] Unweaving the social fabric: the impact of crime on social capital. (May 15, 2003). Centre for U.S.-Mexican Studies. Project on Reforming the Administration of Justice in Mexico. http://www.repositories.cdlib.org/ usmex/prajm/paras.

[30] Glaser, B.G. and Strauss, A.L., The Discovery of Grounded Theory, N.Y. Aldine, 1967. 